навчання (українська мова)»/ Н. В. Гавриш. - К. : Національний педагогічний університет імені М. П. Драгоманова, 2002. - 40 с. 5. Гнізділова О. А. Наукові школи вищих педагогічних навчальних закладів Східної України XX століття: теорія, досвід, перспективи: [монографія] / О. А. Гнізділова // Полтавський нац. пед. ун-т імені В. Г. Короленка. - Полтава : Вид-во ПНПУ імені В. Г. Короленка, 2011. 388 с. 6. Курінна С. М. Особливості соціалізації дітей шести-семи років у різних умовах життєдіяльності: автореф. дис. на здобуття наук. ступеня канд. пед. наук: спец. 13.00.05 «Соціальна педагогіка»/ С. М. Курінна; Луганський національний педагогічний ун-т ім. Тараса Шевченка. - Луганськ, 2004. - 20 с. 7. Лопатіна Г. О. Методика навчання діалогічного мовлення дітей молодшого дошкільного віку: автореф. дис. на здобуття наук. ступеня канд. пед. наук: спец.13.00.02 «Теорія і методика навчання (українська мова)»/ Г. О. Лопатіна. - Луганськ, 2012. - 20 с. 8. Луганський національний універитет імені Тараса Шевченка. Кафедра дошкільної та початкової освіти / Кадровий склад кафедри [Електронний ресурс]. Режим доступу: http://www.luguniv.edu.ua/?z1=b,2500 9. Макаренко I. В. Соціальнопедагогічна підтримка батьків дітей раннього віку 3 особливими потребами: автореф. дис. на здобуття наук. ступеня канд. пед. наук: спец. 13.00.05 «Соціальна педагогіка» / I. В. Макаренко; Луган. нац. ун-т ім. Тараса Шевченка. - Луганськ, 2009. - 20 с. 10. Малахова О. В. Педагогічні умови соціалізації молодших школярів у стосунках з однолітками: автореф. дис. на здобуття наук. ступеня канд. пед. наук: спец. 13.00.05 «Соціальна педагогіка» / О. В. Малахова; Луган. нац. ун-т ім. Тараса Шевченка. - Луганськ, 2007. - 20 с. 11. Міністерство освіти і науки України. Офіційний веб-сайт [Електронний ресурс]. - Режим доступу: http:/www.mon.gov.ua/ua/regionalnews/18894-vitaemo-laureata-dergeavnoyi-premiyiukrayini-v-galuzi-osviti-2013-roku-gavrish-nataliyu-vasilivnu 12. Наукові школи Луганського національного університету імені Тараса Шевченка [Електронний peсурс]. - Режим доступу: http://www.luguniv.edu.ua/?zl=b,1826 13. Саприкіна О. В. Розвиток активного мовлення дітей третього року життя художньо-продуктивній діяльності: автореф. дис. на здобуття наук. ступеня канд. пед. наук: спец. 13.00.02 «Теорія і методика навчання (українська мова)»/ О. В. Саприкіна; Південноукр. держ. пед. ун-т ім. К.Д. Ушинського. - О., 2008. - 20 с.

УДК 378.147

Евгена Гордійчук

\title{
ОСОБЛИВОСТІ СПІВПРАЦІ ВИЩИХ НАВЧАЛЬНИХ ЗАКЛАДІВ УКРАЇНИ ТА ПОЛЬЩІ В КОНТЕКСТІ СВРОІНТЕГРАЦЇ̈
}

Гордійчук Є. С. Особливості співпраці вищих навчальних закладів України та Польщі в контексті євроінтеграції.

У статті розглядаються тенденції розвитку освітньої системи України в аспекті євроінтеграції освіти у контексті Болонської угоди. Досліджено особливості вищої професійної освіти Польщі та обгрунтовано важливість практичного використання вітчизняною професійною освітою прогресивного досвіду цієї країни.

Ключові слова: система професійної освіти, конкурентоспроможність, Болонський процес, європейський ринок праці. 
Гордийчук Е. С. Особенности сотрудничества высших учебных заведений Украины и Польши в контексте евроинтеграции.

В статье рассматриваются тенденции развития образовательной системы Украины в аспекте евроинтеграции образования в контексте Болонского соглашения. Исследованы особенности высшего профессионального образования Польши и обоснована важность практического использования отечественным профессиональным образованием прогрессивного опыта этой страны.

Ключевые слова: система профессионального образования, конкурентоспособность, Болонский процесс, европейский рынок труда.

Gordiychuk T. S. Features of cooperation between higher education institutions of Ukraine and Poland in the context of European integration.

The article deals with the trends of the Ukraine educational system development as a member of the Bologna Union under conditions of the European integration of education. The features of higher education in Poland are investigated and the importance of the practical use of progressive experience in professional education of the Ukraine is proved.

Key words: system of professional education, competitiveness, the Bologna Process, the European labor market.

Проблема визначення перспективних шляхів поступу України, пошуку результативних механізмів у досягненні мети, орієнтації на повноправне членство у загальноєвропейському освітньому просторі та єдиному ринку праці $є$ нагальною в період, коли влада нашої держави веде політику наближення до євростандартів в усіх сферах суспільного та політичного життя.

Професійна освіта України має шанс долучитися до світового освітнього простору за умов оновлення й модернізації опорних ланок освітньої системи в контексті вимог і можливостей третього тисячоліття. В основу перспективного розвитку вітчизняної системи вищої освіти має бути покладена концепція побудови інтеграційної моделі професійної підготовки молоді, здатної до трудової діяльності в умовах зростаючих потоків знань, фінансового капіталу, ресурсів виробництва i сфери послуг [1].

Характерним $є$ те, що до розроблення освітньої політики більшість країн підходять з урахуванням досягнень інших у цій галузі задля формування єдиної освітньої стратегії європейського простору. Вивчаючи особливості побудови, організації й управління, утримання і технології навчання інших країн, вони переймають безцінні надбання, досвід розвитку національних освітніх систем і тим самим сприяють перспективній справі їх зближення, взаєморозуміння, співробітництва.

Актуальність вивчення досвіду Польщі в цій сфері є беззаперечною, адже іiі система освіти вважається однією 3 кращих в Свропі, між навчальними закладами України і Польщі вже налагоджено співпрацю і, звичайно, польська система освіти співвідноситься з вітчизняною.

Як об'єкт дослідження система професійної освіти та навчання розглядалася багатьма як вітчизняними, так i зарубіжними науковцями (Н. Абашкіна, Н. Авшенюк, Ю. Алфьоров, Ф. Андрушкевич, В. Аранський, А. Баранников, Н. Бідюк, Г. Бутенко, Б. Вульфсон, А. Воскресенська, С. Глазунова, О. Глузман, Т. Десятов, О. Джуринський, В. Кремень, В. Кудін, О. Кузнєцова, В. Лапчинська, М. Ларіонова, В. Ледньов, 3. Малькова, О. Матвієнко, А. Муравйова, Н. Ничкало, О. Овчарук, О. Олейнікова, Л. Петренко, Л. Пуховська, В. Радкевич, А. Сбруєва, 
С. Сисоєва, I. Смирнов, Л. Хомич, V. Dael, G. Delor, C. Kupisiewicz, J. Auwerijs, F. Mayor, D. Mertens, T. Nowacki, D. Thierry, F. Szlosek, D. Scholz, K. Symela, Z. Wiatrowski, D. Wortmann та ін.), які вказують на те, що системи вищої професійної освіти різних країн відрізняються, але загальні тенденції мають спільний характер в питаннях пошуку якості, безперервності, інтернаціоналізації, демократизації, гнучкості, мобільності, професійної освіти й навчання у його своєрідних національних формах [5].

Meта статmi - розглянути особливості співпраці вищих навчальних закладів України і Польщі в контексті євроінтеграції та обгрунтувати важливість вивчення й упровадження досвіду Польщі.

Процес входження України до об'єднаної Свропи в галузі освіти розпочався ще 19 травня 2005 року на конференції міністрів освіти європейських країн в норвезькому місті Берген, коли Україну було прийнято у члени Болонського союзу, до якого входить вся Європа.

Головною структурною реформою вищої освіти на європейському просторі $\epsilon$ Болонський процес, який було започатковано в університеті італійського міста Болонья. Болонський процес - система заходів європейських державних установ (на рівні міністерств освіти), університетів, міждержавних і громадських організацій, пов'язаних із вищою освітою, спрямована на реформування національних систем вищої освіти країн Європи, зміни освітніх програм і потрібних інституційних перетворень задля створення європейського наукового й освітянського простору для підвищення спроможності випускників вищих навчальних закладів до працевлаштування, поліпшення мобільності на європейському ринку праці, підвищення конкурентоспроможності європейської вищої школи.

Приєднавшись до Болонського процесу, Україна зіткнулася із низкою проблем, які потребували розв'язання в найближчому майбутньому. В Україні було створено Національну групу промоутерів Болонського процесу (National Team of Bologna Promoters), до якої залучили фахівців провідних університетів України. Вони брали участь у навчальних тренінгах 3 актуальних проблем вищої освіти на Європейському освітньому просторі і відповідно в Україні проводилися навчальні тренінги за такими основними напрямами:

- забезпечення якості вищої освіти;

- трициклова система освіти;

- система кваліфікацій європейського освітнього простору.

У 2006/07 навчальному році у всіх ВНЗ України III-IV рівнів акредитації запроваджено кредитно-трансферну систему. Підготовлено відповідний Пакет інноваційних нормативних документів для цієї системи, розроблено рекомендації та здійснюються організаційні заходи із запровадження Додатка до диплома європейського зразка.

Визнання кваліфікацій вищої освіти регулюється Законами України «Про освіту», «Про вищу освіту», Постановами Кабінету Міністрів України № 1260 «Про документи про освіту та вчені звання» та № 1380 «Про ліцензування освітніх послуг», наказом Міністерства освіти і науки України № 563 «Про затвердження Положення про визнання іноземних документів про освіту», де визначаються правові та організаційні основи визнання іноземних освітніх документів. Ці нормативні документи встановлюють централізовану процедуру визнання, що входить до компетенції Міністерства освіти і науки України. Національні критерії оцінювання якості іноземних кваліфікацій, отриманих у різних регіонах світу, 
грунтуються на положеннях Лісабонської Конвенції. Реалізацію цих функцій у міністерстві здійснює підрозділ управління ліцензування, акредитації та нострифікації.

Минулий 2012 рік був наповнений різноманітними заходами у руслі Болонського процесу, спрямованими на розвиток подальшого прогресу у формуванні Свропейського простору вищої освіти. Серед них особливого значення мали результати Восьмої Болонської конференції міністрів освіти і Третього Болонського політичного форуму, які відбулися 26-27 квітня 2012 р. в Бухаресті (Румунія). Делегації міністерств освіти 47 країн Європейського простору вищої освіти (далі - СПВО) та делегації 40 держав, що не водять в ЄПВО, а також 23 міжнародні й регіональні організації взяли участь у роботі цих форумів.

Українська делегація на чолі 3 міністром освіти і науки, молоді та спорту України Д. Табачником також взяла участь у конференції. Метою участі стала дискусія та аналіз діяльності в межах Болонського процесу за таким напрямком роботи, як завершення структурних реформ, що повинні продовжуватися в різних частинах європейського простору вищої освіти.

Усі ці заходи наближають вищу освіту України до рівня європейського, але головна мета, а це визнання українських дипломів у країнах Свропи - поки що в перспективі.

Логічно, що проведення реформаційних освітніх змін необхідно здійснювати, спираючись на досвід, проблеми тих країн, які, зважаючи на різні суспільнополітичні, соціально-економічні обставини, на цьому шляху зробили або роблять випереджальні кроки. Однією з таких країн є сусідня Польща.

Модель польської освітньої системи вважається однією з провідних у світі. За визначенням Центру європейської освіти (European Education Center), дипломи польських навчальних закладів визнаються у всіх країнах Європи та не потребують спеціальної нострифікації (процедури визнання іноземних документів про освіту, яка здійснюється шляхом встановлення відповідності академічних, професійних та освітніх, освітньо-кваліфікаційних рівнів іноземних документів про освіту державним стандартам освіти задля забезпечення прав громадян, що здобули освіту в іноземних державах, на продовження освіти та професійну діяльність в Україні) [1].

У сучасній Польщі здійснюється глибока реформа змісту освіти. Завдання підвищити якість та ефективність освіти привело до його глибокої структурної перебудови, спрямованої на подолання суперечностей між швидким приростом наукового знання й обмеженими можливостями його засвоєння учнями та студентами. Йдеться про збагачення змісту навчальних програм матеріалом, який інтегрує знання, наближає викладання низки дисциплін до європейських стандартів.

Польща належить до групи «молодих країн» Євросоюзу, тому освіта сьогодення $\epsilon$ основним засобом підготовки молоді до життя в Європі. Найважливішими фундаментальними властивостями університету Польщі $є$ автономія, свобода ведення наукових досліджень і освіти. Сучасний університет піддається тиску і втручанню лише на користь функції, що професіоналізується, відповідно до вимог ринку праці. Нині університет еволюціонує до ринкової моделі. Урахування потреб студентів веде до того, що найважливішим i вищим завданням університетської освіти $\epsilon$ гарантування iї учасникам компетенцій (вони відносяться до кінцевих результатів навчання і $є$ складними уміннями вищого рівня). Ключовими для сучасного студента $€$ такі компетенції: навчання, мислення, пошук, самовдосконалення, комунікація, співпраця, діяльність. Вони орієнтовані на розвиток самостійності і відповідальності 
молодих поляків і показують одночасно значення підготовки сучасних студентів до безперервної освіти, самоосвіти і вдосконалення [3].

Тому на нинішньому етапі розвитку вищої освіти України як європейської орієнтація на успішну в цій сфері Польщу є кроком уперед. Співпраця українських і польських вищих навчальних закладів задля взаємного визнання дипломів, а відтак забезпечення конкурентоспроможності молодих фахівців на європейському ринку праці є стратегічно важливим питанням.

Одним із важливих кроків у напрямі українсько-польської співпраці $\epsilon$ підписання угоди між Варшавським університетом наук про життя (SGGW) та Національним університетом біоресурсів та природокористування України (НУБіП України), що грунтується на меморандумі Взаєморозуміння, підписаного 22.12.2010 р., встановлює взаємний внесок в академічну освіту, науку і технологічний розвиток обох сторін і заохочує до обміну науковими дослідженнями. Метою цього заходу $є$ встановлення двоступеневої програми, що дозволить студентам SGGW і НУБіП України отримувати ступінь магістра в університеті-партнері. Студенти 3 SGGW отримають ступінь магістра в НУБіП України, а також ступінь магістра в SGGW, коли вони навчатимуться за двоступеневою програмою в обох університетах. Аналогічно студенти з НУБіП України отримують ступінь магістра в SGGW, a також ступінь магістра в НУБіП України. Методичне підгрунтя цього експерименту полягає в узгодженні навчальних планів обох університетів. Тобто ті дисципліни, які відсутні в нормативній частині робочого плану НУБіП України, але $є$ у нормативній частині робочого плану SGGW, мають бути внесені у вибіркову його частину. Таким же чином корегується вибіркова частина робочого плану польської сторони для забезпечення відповідності засвоєного матеріалу, оволодіння знаннями та уміннями студентів, які отримають диплом в університеті-партнері.

Студенти факультету енергетики та автоматики НУБіП України мають можливість навчатися протягом кількох місяців в польському університеті, i відповідно польські студенти приїжджають на навчання до Києва. Студенти НУБіП України, які успішно завершили програму бакалавра i розпочинають програму магістра, мають право подати заяву для подальшого проходження програми магістра в SGGW. Кандидати мають бути компетентні в польській (англійській) мові і бути рекомендованими НУБіП України. Кожен студент за програмою має індивідуального наукового керівника від SGGW.

Відповідно студенти від SGGW, які успішно завершили програму бакалавра i розпочинають програму магістра, мають право подати заяву для подальшого проходження програми магістра в НУБіП України. Кандидати мають бути компетентні в українській (російській або англійській) мові і бути рекомендованими SGGW. Кожен студент також має індивідуального наукового керівника від НУБіП України.

На шляху до євроінтеграції освіти Україна поетапно робить послідовні кроки в реформуванні системи вищої освіти у руслі вимог відповідно до зазначених основних напрямів Болонського процесу: за ці роки були внесені зміни в закони України «Про освіту», «Про вищу освіту», Національну доктрину розвитку освіти, якими засвідчується здатність держави трансформувати освітній простір до вимог і стандартів Болонської декларації і зумовлюються об'єктивні орієнтири стратегії розвитку української національної освіти. Але відкритими залишаються ще багато питань, відповіді на які можна знайти, зокрема, в одній із провідних європейських країн в галузі освіти - Польщі. Така практика співпраці та перейняття досвіду $є$ 
поширеною і актуальною в сучасному суспільстві. Результати дослідження моделі польської освітньої системи дають змогу констатувати, що під час розроблення стратегії розвитку вищої освіти в Україні особливо пізнавальним є досвід сусідньої Польщі.

Перспективи подальших досліджень полягають у вивченні потенційних можливостей українсько-польської співпраці у професійній підготовці фахівців різного профілю.

1. Андрушкевич Ф. Польський «освітній прорив» та його значення для українських освітніх інновацій / Ф. Андрушкевич // Вища освіта в Україні. - 2010. № 4. - С. 103-108. 2. Міжнародні програми навчання за кордоном [Електронний pecypc] - Режим доступу: http://www.ksada.org/html/int3u.html 3. Общая справка о системе образования в Польше [Электронный ресурс]. - Режим доступу: http://www.educationsystems.info/item466.html 4. Програма розвитку вищої освіти України «Основні засади розвитку вищої освіти України в контексті Болонського процесу» / за редакцією В. Г. Кременя. упорядники: М. Ф. Степко, Я. Я. Болюбаш, В. Д. Шинкарук, В. В. Грубінко, І. І. Бабин / Київ - Тернопіль : Видавництво ТДПУ, 2004. - 147 c. 5. Савина А. К. Польша: международная тематика в содержании общего образования / А. К. Савина // Педагогика. - 2010. - № 2. - С. 94-99.

УДК 37.014 .3

Ірина Колесник

\section{ІДЕЇ РЕФОРМУВАННЯ ОСВІТИ В ЗАХІДНІЙ СВРОПІ В ПЕРІОД ХІХ СТОЛІТТЯ}

Колесник I. О. Ідеї реформування освіти в Західній Європі в період XIX століття.

У статті розкрито роль національних освітніх перетворень, визначено основні чинники розвитку педагогічної науки, глобальні тенденції розвитку освіти, характерні для країн Свропи й США досліджуваного періоду. Доведено, що реформування шкільної системи сприяло інтенсивному промисловому зростанню, розвитку педагогічної науки, а також відбиває потребу суспільства в підготовці через школу різнобічно розвинених, ініціативних людей, готових до активної діяльності в різних галузях економічного, політичної й громадського життя.

Ключові слова: держава, освіта, школа, гімназія, університет, реформування, розвиток, релігія.

Колесник И. А. Идеи реформирования образования в Западной Европе в период XIX века.

В статье раскрыта роль национальных преобразований, определены основные факторы развития педагогической науки, глобальные общие тенденции реформирования образования, характерные для стран Европы и США исследуемого периода. Доказано, что реформирование школьной системы способствовало интенсивному промышленному росту, развитию педагогической науки, а также отражает потребность общества в подготовке через школу разносторонне развитых, инициативных людей, готовых к активной деятельности в различных областях экономической, политической и общественной жизни. 